\title{
IMPACT OF INULIN ON PRODUCTION OF METHANE, CARBON DIOXIDE AND GASTROINTESTINAL CANAL FUNCTIONALITY IN CALVES
}

\author{
Sintija Jonova1 ${ }^{1}$ Aija Ilgaza ${ }^{1}$, Inga Grinfelde ${ }^{1}$, Maksims Zolovs ${ }^{2}$ \\ ${ }^{1}$ Latvia University of Life Sciences and Technologies, Latvia \\ ${ }^{2}$ Daugavpils University, Latvia \\ sintija.jonova@gmail.com
}

\begin{abstract}
Ruminants produce a large amount of methane $\left(\mathrm{CH}_{4}\right)$ and carbon dioxide $\left(\mathrm{CO}_{2}\right)$ in their foregut. These gases cause greenhouse effect. There are a lot of studies about different feed additives which can reduce the production of greenhouse gases in ruminants. Prebiotics can also change the amount of bacteria in animal gastrointestinal tract and reduce the occurrence of diarrhoea. The aim of this study was to test whether the prebiotic inulin affects the production of $\mathrm{CH}_{4}$ and $\mathrm{CO}_{2}$ in calves' rumen and whether it affects the bacteria count in the rumen fluid and bacterial overgrowth in intestines. We used the flour of Jerusalem artichoke (Helianthus tuberosus L.) containing $50 \%$ of inulin. Approximately fifty days old, Holstein Friesian crossbreed calves were used in this study. Eight were in the control group, 8 received $12 \mathrm{~g}$ of flour and 8 received $24 \mathrm{~g}$ per day. On the $28^{\text {th }}$ and $56^{\text {th }}$ day of the research, we measured the amount of $\mathrm{CH}_{4}$ and $\mathrm{CO}_{2}$ in calves' rumen, took rumen fluid samples for bacterial analysis and urine to measure the level of phenol and indican. We concluded that adding the flour of Jerusalem artichoke at doses $12 \mathrm{~g}$ and $24 \mathrm{~g}$ did not significantly impact the production of $\mathrm{CH}_{4}$ and $\mathrm{CO}_{2}$ in calves' rumen, the prebiotic inulin may suppress the growth of anaerobic microorganisms in the rumen at concentration $12 \mathrm{~g}$ of inulin reaching $56^{\text {th }}$ day of experiment. The amount of phenol and indican in calves' morning urine did not correlate with the faecal consistency of calves.

Key words: calves, inulin, methane, carbon dioxide, phenol, indicant.
\end{abstract}

\section{Introduction}

Greenhouse gas effect negatively affects ecosystem in the whole world and can cause tremendous climate changes. Unfortunately, the development of the economic activity, including agricultural sector, negatively affects the emission of gases, which causes the greenhouse effect. Many countries invest enormous resources to decrease the greenhouse effect (Jordaan et al., 2017). After regaining independence, Latvia took active part in reducing the greenhouse effect by finding different solutions to reduce these emissions in different sectors of economic activity (Lenerts, Popluga, \& Rivza, 2017).

In Latvia, greenhouse gas (GHG) emission is actual in dairy cattle and beef cattle farms where the emission of nitrous oxide $\left(\mathrm{N}_{2} \mathrm{O}\right)$ and methane $\left(\mathrm{CH}_{4}\right)$ can reach 83-94\%, but carbon dioxide $\left(\mathrm{CO}_{2}\right) 6-17 \%$ of the total gas amount (Kreišmane, 2011).

Bērzina with her colleagues found out that, in 2012, emissions produced in agriculture sector contributed approximately $20 \%$ of the total emissions in Latvia and it was the second largest source of GHG emissions (Bērziña et al., 2014). There were 393.1 thousand cattle in Latvia (2012); dairy cows were 164.6 thousand from them (Centrālā..., 2013). The most recent data show that, in 2016, the number of cattle in Latvia rose to 412 084, dairy cows - 153927 from them (Latvijas..., 2017), therefore, it may be concluded that emissions have risen.

Ruminants have a stomach consisting of four compartments; the largest is rumen with enormous number of microorganisms providing biological digestion processes of feed. Due to these processes, two major gases $\mathrm{CO}_{2}$ and $\mathrm{CH}_{4}$ are produced in large quantities making $65.5 \%$ and $26.8 \%$ respectively (Chianese, Rotz, \& Richard, 2009). Some of the $\mathrm{CO}_{2}$ producing microorganisms in the rumen are Ruminococcus albus, Butyrivibrio fibrisolvens and Lachospira multiparus. Methanobacterium ruminatium and Methanobacterium mobilis and other methanogens produce $\mathrm{CH}_{4}$ by using hydrogen $\left(\mathrm{H}_{2}\right)$ and $\mathrm{CO}_{2}$ produced by other fermentative members of the rumen microbiome (Rother \& Krzycki, 2010). It is known that $\mathrm{CO}_{2}$ and $\mathrm{H}_{2}$ are major precursors of $\mathrm{CH}_{4}$ (Asanuma, Iwamoto, \& Hino, 1999).

Although agriculture is not considered to be the main source of $\mathrm{CO}_{2}$ emissions, still $\mathrm{CO}_{2}$ emissions occur on farms, mainly due to animal respiration and decomposition of soil organic matter (Chianese, Rotz, \& Richard, 2009). The same authors made conclusions that $\mathrm{CO}_{2}$ emission from animal respiration make up to $90 \%$ of the total $\mathrm{CO}_{2}$ emissions on a dairy farm. Although $\mathrm{CH}_{4}$ is 23 times more potent than $\mathrm{CO}_{2}$, it still should be considered when talking about GHG (Loh et al., 2008).

Methane production is considered an energy loss for the host (Kristensen et al., 2011). There are a lot of factors impacting the production of $\mathrm{CH}_{4}$ in rumen, such as animal size, growth rate, level of intake, feed quality, genetics, and environmental temperature (Shibata \& Terada, 2010). It is impossible to completely stop methanogenesis in rumen as it is the integral component of rumen fermentation (Cengic-Dzomba, Dzomba, \& Musanovic, 2012). GHG emission may be decreased either by increasing the productivity of the animal through improved nutrition to produce less 
$\mathrm{CH}_{4}$ per unit of meat or milk or by altering the rumen fermentation process (Iqbal et al., 2008).

The promising results of prebiotics on human health have encouraged researchers to explore its potential on different livestock species like cattle, sheep and other ruminants (Fraser et al., 1998; Nabuurs, 1998). Feed additives have the potential to improve nutrient utilization in farm animals by modifying ruminal microbial population and, consequently, ruminal fermentation and digestion (McGuffey, Richardson, \& Wilkinson, 2001). Many researchers have found that prebiotics can increase the daily weight gain in calves and have potential to reduce $\mathrm{CH}_{4}$ production (Mwenya et al., 2004; Hasunuma et al., 2011; Ilgaza et al., 2016).

The prebiotic inulin was used in the present research. It is a polydisperse non-starch polysaccharide naturally occurring as a storage carbohydrate in some 36000 species of plants. The main sources of inulin are chicory (Cichorium intybus L.) and Jerusalem artichoke (Helianthus tuberosus L.). Inulin is used successfully in monogastric animals, however, there is not enough evidence of its use in ruminants. The process of fermentation that occurs in the large intestines of monogastric animals is identical to that occurring in the forestomach of ruminants (Öztürk, 2008). Several studies have revealed that adding inulin to the milk replacer of pre-ruminant calves leads to significantly higher live-weight gains and better faecal consistency (Kaufhold, Hammon, \& Blum, 2000; Verdonk \& Van Leeuwen, 2004). There is no information about the impact of inulin on the production of $\mathrm{CH}_{4}$ and $\mathrm{CO}_{2}$ in the rumen of calves.

Mul (1997) found that adding oligofructose to the milk replacer of calves resulted in improved body weight gains, feed conversion efficiency, firmer faeces and reduction of diarrhoea. The same results were recorded in the study where prebiotic inulin was used (Ārne \& Ilgaža, 2016). Faecal consistency may also be affected by bacterial overgrowth in intestines. In human medicine, the quantitative evidence of phenols in night and morning urine with increased values is a reliable indicator of bacterial overgrowth in intestines. With the help of special analysis of phenol and indican, it is furthermore possible to locate a growth in the intestine. Phenol mainly is resorbed in the small intestine, indican is a bacterial metabolic product, which is resorbed in colon (Toskes, 1999; Lord \& Bralley, 2008). Acknowledging it, we asked whether inulin supplement changes the amount of phenol and indican in calves' morning urine and whether these changes are related to faecal consistency.

Phenol is formed in the bowel from amino acid tyrosine and is eliminated to a considerable extent in the faeces. Part of it is absorbed and excreted largely unchanged in urine (Smith \& Macfarlane, 1997).
Indican is an end-product of indole produced when bacteria in the intestine act on the amino acid, tryptophan. Most indoles are excreted in faeces. The rest is absorbed, metabolized by the liver, and excreted as indican in urine (Greenberger, Saegh, \& Ruppert, 1968; Jackson, Riordan, \& Neathery, 2000). Indican is an indicator of overgrowth of anaerobic bacteria (Greenberger, Saegh, \& Ruppert, 1968).

The aim of this study was to find out how the prebiotic inulin affects the production of $\mathrm{CH}_{4}$ and $\mathrm{CO}_{2}$ in calves' rumen on $1 \mathrm{~kg}$ body weight and how it affects the bacteria count in rumen fluid and the bacterial overgrowth in intestines. Previously it has been found that inulin supplement positively affects calves' live weight gain and faecal consistency (Jonova, Ilgaza, \& Grinfelde, 2017).

\section{Materials and Methods}

The research was conducted in a dairy farm of intensive production from July until the end of September, 2016. The farm is located in Jelgava district (latitude: N 56 27', longitude: E $23^{\circ} 37^{\prime}$ ) Latvia. Clinically healthy different sex Holstein Friesian (Bos taurus L.) crossbreed calves were included in our research. Their average age was 49 \pm 10 days and average weight was $79.6 \pm 12.82 \mathrm{~kg}$. Calves were kept in groups in a partly closed space with natural ventilation through windows.

Eight calves were in the control group (CoG), 8 were fed with additional $12 \mathrm{~g}$ of flour of Jerusalem artichoke containing $6 \mathrm{~g}$ of prebiotic inulin (Pre12) and 8 received $24 \mathrm{~g}$ of this flour containing $12 \mathrm{~g}$ of inulin (Pre24). These dosages were chosen to compare the results with the results from the previous research in a different farm. Jerusalem artichoke contains just around $10 \%$ of inulin, but by using special technologies, the content of inulin can be increased up to $48.5-50 \%$ (Fleming \& Groot, 1979). Inulin supplement, which is used in this study, is produced in Latvia. We added this prebiotic to barley flour once a day. All calves had free access to water and hay and they also got whole milk (2.5 - $3 \mathrm{~L}$ per calf twice a day) and a calf starter meal (0.5 kg per calf once a day) (Ilgaza et al., 2016; Jonova, Ilgaza, \& Grinfelde, 2017).

The research lasted for two months (56 days). Methane and carbon dioxide were measured by using cavity ring down spectroscopy device Picarro G2508 connected in the closed circulation system with $1 \mathrm{~L}$ chamber and external zero leaching vacuum pump. The air samples from calves' rumens were collected on the $28^{\text {th }}$ and $56^{\text {th }}$ day of the research. Each sample of calves' rumen gas was taken in syringes with $20 \mathrm{~mL}$ volume by puncturing the rumen at the point where the gas accumulation was visually noticed. $10 \mathrm{~mL}$ of calf's rumen gas were injected in the chamber with air and measured for $180 \mathrm{~s}$. 
The rumen fluid was obtained by puncturing the rumen at a lower point and aspirating the fluid in the syringe $2 \mathrm{~h}$ after feeding. Then samples were securely closed to maintain an anaerobic environment and frozen at $-80{ }^{\circ} \mathrm{C}$. The count of anaerobic bacteria in rumen fluid was determined by growing viable anaerobic bacteria from rumen fluid samples at $10^{-6}$ dilution on plate count agar. Petri dishes were incubated in anaerobic conditions at $+37^{\circ} \mathrm{C}$ for 3 days. Bacteria colonies were counted, and bacteria count in one millilitre of rumen fluid was mathematically calculated and converted to logarithmic scale. Testing was performed in Latvia University of Life Sciences and Technologies, Scientific Laboratory of Biotechnology, Department of Molecular Biology and Microbiology.

The urine was collected early in the morning before feeding by catching urine flow in the middle. The samples were stored in special urine vacutainers with preservative to keep it stable and kept in a dark place. Samples were sent to Laboklin laboratory in Germany for testing for phenol and indican (indicators for bacterial overgrowth in small intestines) by using standardized chemical photometric method.

On the $28^{\text {th }}$ and $56^{\text {th }}$ day of the research faecal consistency was evaluated. Faeces were scored for physical shape as 1 : firm; 2 : slightly loose; 3 : loose; 4 : watery (Larson et al., 1977).

The assumption of normal data distribution was assessed by Shapiro-Wilk's test and visual inspection of their histograms, normal Q-Q plots and box plots. The assumption of homogeneity of variances was tested by Levene's test. Box plots detected presence of outliers. To determine whether there were any statistically significant differences among three or more independent groups, one-way ANOVA (with Tukey post hoc test) (if the data were normally distributed, homogeneous and without outliers) was used. Otherwise, the data were analysed using the Kruskal - Wallis $\mathrm{H}$ test with pairwise comparisons using Dunn's (1964) procedure with a Bonferroni adjustment. To determine if there was a statistically significant monotonic trend between an ordinal independent variable and a continuous variable the Jonckheere-Terpstra test was used, however, it does not inform how strong this trend might be. Therefore, Kendall's tau-b $(\tau b)$ was used as a measure of effect size (Kraska-Miller, 2014). Those tests were carried out using SPSS Statistics version 22 (IBM Corporation, Chicago, Illinois). All statistical analyses were performed at the significance level of $\alpha=0.05$.

\section{Results and Discussion}

In this study it was found out that the production of $\mathrm{CH}_{4}$ on $1 \mathrm{~kg}$ body weight on the $28^{\text {th }}$ day of the research was the highest in Pre12 but the lowest in
Pre24 $\left(11.9 \pm 2.94 \mathrm{mg} \mathrm{m}^{-3}\right.$ and $9.2 \pm 1.06 \mathrm{mg} \mathrm{m}^{-3}$, respectively), but in CoG $-10.1 \pm 2.46 \mathrm{mg} \mathrm{m}^{-3}$, the situation changed at the end of the research, the lowest production of $\mathrm{CH}_{4}$ on $1 \mathrm{~kg}$ body weight now was in CoG, but the highest in Pre24 (7.2 $\pm 1.68 \mathrm{mg} \mathrm{m}^{-3}$ and $9.1 \pm 2.45 \mathrm{mg} \mathrm{m}^{-3}$, respectively), but in Pre12 $-8.0 \pm$ $1.53 \mathrm{mg} \mathrm{m}^{-3}$ ). Similar tendency was observed about $\mathrm{CO}_{2}$. The highest $\mathrm{CO}_{2}$ production on $1 \mathrm{~kg}$ body weight on the $28^{\text {th }}$ day of the research was in Pre12, but it was the lowest in Pre24 (49.1 $\pm 10.54 \mathrm{mg} \mathrm{m}^{-3}$ and $39.0 \pm$ $8.81 \mathrm{mg} \mathrm{m}^{-3}$, respectively), but in CoG $-42.9 \pm 6.98$ $\mathrm{mg} \mathrm{m}^{-3}$. On the $56^{\text {th }}$ day of the research the highest $\mathrm{CO}_{2}$ production on $1 \mathrm{~kg}$ body weight was observed in groups fed with additional inulin supplement, but the lowest in CoG (Pre12 - 46.1 $\pm 8.52 \mathrm{mg} \mathrm{m}^{-3}$, Pre24 $-43.4 \pm 11.12 \mathrm{mg} \mathrm{m}^{-3}$ and $\mathrm{CoG}-39.1 \pm 10.93$ $\mathrm{mg} \mathrm{m}^{-3}$ ). Numerous studies show that prebiotics can reduce the production of $\mathrm{CH}_{4}$. For example, galactooligosaccharides can reduce the production of $\mathrm{CH}_{4}$ up to $11 \%$ (Mwenya et al., 2004). Our results are contrary, the analysis of production of $\mathrm{CH}_{4}$ and $\mathrm{CO}_{2}$ on $1 \mathrm{~kg}$ body weight showed that there were no significant outliers, data were normally distributed for each group, and there was homogeneity of variances. The one-way ANOVA showed that there was no significant difference between experimental and control groups ( $p>0.05)$. It means that adding the flour of Jerusalem artichoke at doses $12 \mathrm{~g}$ and $24 \mathrm{~g}$ does not significantly influence the production of $\mathrm{CH}_{4}$ and $\mathrm{CO}_{2}$ in calves' rumen. We suggest that other dosages of inulin or other feed additives should be chosen for mitigation of GHG.

A lot of microorganisms living in the rumen use prebiotics as the source of energy (Samanta et al., 2013). Bunce, Howard \& Kerley (1995) found that the inclusion of prebiotic oligosaccharides into the diet of calves reduces the population of total anaerobes in the gut.

Data of the present study showed that the count of anaerobic bacteria in rumen fluid was not normally distributed, however, conversion to logarithmic scale has made data normally distributed. A Welch t-test was run to determine if there were differences in log of anaerobic bacteria between experimental and control groups due to the assumption of homogeneity of variances being violated, as assessed by Levene's test for equality of variances $(F(5.42)=7.224, p<0.001)$.

The Tukey post hoc test showed that the log of anaerobic bacteria was significantly lower in experimental group Pre24 on $56^{\text {th }}$ day comparing to CoG on the $28^{\text {th }}$ and $56^{\text {th }}$ day and Pre24 on the $28^{\text {th }}$ day and Pre12 on the $28^{\text {th }}$ day $(\mathrm{p}<0.05)$ (Fig 1.).

The rumen only starts to grow at 2-3 weeks of age and its growth will continue until about 6 months. Calves can be called full-ruminants at 12 weeks of age when their rumen has fully developed and calves are 


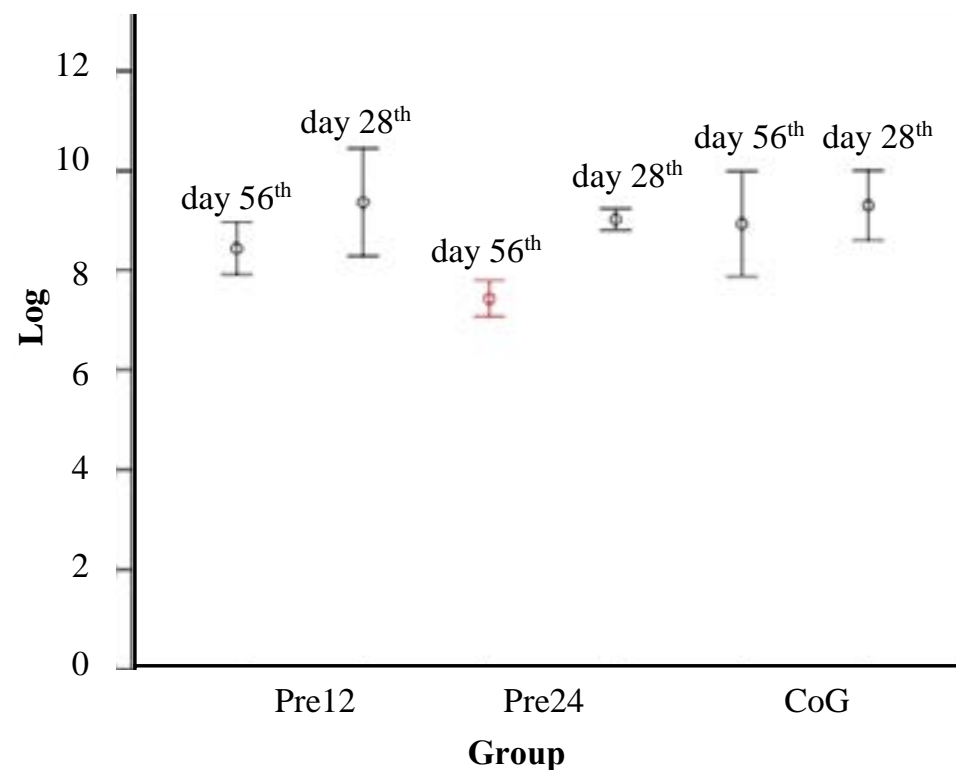

Figure 1. The amount of viable anaerobic microorganisms in the rumen fluid on different sampling days.

able to eat and digest dry food at the level of adult ruminants (Govil et al., 2017). Ruminant animals harbor a complex microbial community consisting of a diverse array of anaerobic microbes in the rumen (Fathallh Eida et al., 2012). These microorganisms interact with one another and take part in the systematic digestion of fibrous plant material, which they anaerobically ferment into end products later used as energy sources by the host (Martin, Morgavi, \& Doreau, 2010). Our results suggest that the prebiotic inulin may suppress the growth of anaerobic microorganisms in the rumen at concentration $12 \mathrm{~g}$ of inulin reaching the $56^{\text {th }}$ day of experiment.

Median of phenol in calves' morning urine in three study groups was $681.1 \mathrm{mg} \mathrm{dL}^{-1}$ for $\operatorname{CoG}(\mathrm{n}=9)$, $675.0 \mathrm{mg} \mathrm{dL}^{-1}$ for Pre12 (n=7) and $384.5 \mathrm{mg} \mathrm{dL}^{-1}$ for Pre24 $(n=8)$. A Jonckheere-Terpstra test determined that there was a statistically significant decreasing monotonic trend in median of phenol in calves' morning urine, $p=0.032$. Kendall's $\tau_{b}$ between study groups and phenol level was -0.353 (moderate effect size). Median of indican in calves' morning urine in three study groups was $40.0 \mathrm{mg} \mathrm{dL}^{-1}$ for CoG $(\mathrm{n}=9)$, $20.0 \mathrm{mg} \mathrm{dL}^{-1}$ for Pre12 (n=7) and $10 \mathrm{mg} \mathrm{dL}^{-1}$ for Pre24 $(\mathrm{n}=8)$. A Jonckheere-Terpstra test determined that there was a statistically significant decreasing monotonic trend in median of indican in calves' morning urine, $\mathrm{p}=0.002$. Kendall's $\tau_{\mathrm{b}}$ between study groups and indican level was -0.534 (strong effect size). It means that there is moderate negative association between dosage of inulin and phenol in calves' morning urine, as well as strong negative association between dosage of inulin and indican in calves' morning urine. The level of indican and phenol in the urine decreases with a higher dosage of inulin.
Hidaka et al. (1986) supplemented rat diets with short-chain fructooligosaccharides and observed that concentrations of phenols in urine samples decreased, whereas the concentration of indican did not change. Those data only partly coincide with our results, because we recorded decrease of both phenol and indican.

These two substances - indican and phenol are considered to be the indicators of the bacterial overgrowth in the intestines and can affect the faecal consistency in humans and monogastric animals (Toskes, 1999; Lord \& Bralley, 2008). Although during the implementation of this study, changes in the amount of phenol and indican were observed, these changes were not related to the faecal consistency $(\mathrm{p}>0.05)$. On the $28^{\text {th }}$ day recorded results were as follows in Pre12 Me = 2 (IQR 1.25 - 2.75), Pre24 Me $=1(\mathrm{IQR} 1-2), \mathrm{CoG} \mathrm{Me}=2(\mathrm{IQR} 1-2)$ and on the $56^{\text {th }}$ day: in Pre12 Me = 2 (IQR 1 - 2), Pre24 Me = 2 (IQR $1-2)$, CoG Me = 1 (IQR $1-2$ ). Faecal consistency shows that faeces were quite firm in all groups on sampling days and the difference between scores was not significant. However, we cannot confirm that the bacterial overgrowth in the intestines has any connection with the level of phenol and indican in the calves' urine.

\section{Conclusions}

1. The flour of Jerusalem artichoke at doses $12 \mathrm{~g}$ and $24 \mathrm{~g}$ does not reduce the production of $\mathrm{CH}_{4}$ and $\mathrm{CO}_{2}$ in calves' rumen at age $49 \pm 10$ days.

2. The prebiotic inulin may suppress the growth of anaerobic microorganisms in the rumen at concentration $12 \mathrm{~g}$ of inulin reaching the $56^{\text {th }}$ day of experiment. 
3. The amount of phenol and indican in calves' morning urine does not correlate with the faecal consistency of calves, however, it negatively correlates with inulin's concentration in feed.

\section{Acknowledgements}

This research has been supported by the National Research Programme Agricultural Resources for Sustainable Production of Qualitative and Healthy Foods in Latvia (AgroBioRes) (2014 - 2017).

\section{References}

1. Asanuma, N., Iwamoto, M., \& Hino, T. (1999). Effect of the addition of fumarate on methane production by ruminal microorganisms in vitro. J. Dairy Sci. 82, 780-787. DOI: 10.3168/jds.S0022-0302(99)752963.

2. Ārne, A., \& Ilgaža, A. (2016). Different dose inulin feeding effect on calf digestion canal state and development. In Research for Rural Development - International Scientific Conference, 18-20 May 2016, Vol. 1 (pp. 116-119). Jelgava, Latvia: LLU.

3. Bērziņa, L., Sudārs, R., Priekulis, J., \& Baranovska, E. (2014). Pētījuma 'Siltumnīcefekta gāzu emisiju aprēkinu veikšana lauksaimniecības sektorā par 2012. gadu atskaite (Research 'Calculations of greenhouse gas emission in agricultural sector about the year 2012' report). LLU. Retrieved January 15, 2018, from: https://www.zm.gov.lv/public/ck/files/ZM/TP\%20petijumi/Siltumnicu\%20gazu\%20emisiju\%20 aprekinu\%20veiksana_2012_2014g.pdf. (in Latvian).

4. Bunce, T.J., Howard, M.D., \& Kerley, M.S. (1995). Protective effect of fructooligosaccharides in prevention of mortality and morbidity from infectious E.coli K88 challenge. J Anim Sci. 63(1), 1784-1788.

5. Cengic-Dzomba, S., Dzomba, E., \& Musanovic, E. (2012). Different nutritional strategies for reducing methane emissions from ruminants: natural feed additives as alternative to chemicals. In Proceedings of the $22^{\text {nd }}$ International Scientific-Expert Conference of Agriculture and Food Industry, 28 September - 1 October 2011 (pp. 18-20). Sarajevo, Bosnia and Herzegovina: Ege University, Faculty of Agriculture.

6. Centrālā statistikas pārvalde. (2013). Main indicators of livestock farming in 2012. Retrieved January 15, 2018, from: http://www.csb.gov.lv/en/notikumi/main-indicators-livestock-farming-2012-36382.html.

7. Chianese, D.S., Rotz, C.A., \& Richard, T. (2009). Simulation of Carbon Dioxide Emissions from Dairy Farms to Assess Greenhouse Gas Reduction Strategies. Transactions of the ASABE. 52(4), 1301-1312. DOI: $10.13031 / 2013.27780$.

8. Dunn, O.J. (1964). Multiple comparisons using rank sums. Technometrics. 6, 241-252.

9. Fathallh Eida, M., Nagaoka, T., Wasaki, J., \& Kouno, K. (2012). Isolation and characterization of cellulosedecomposing bacteria inhabiting sawdust and coffee residue composts. Microbes and Environments. 27(3), 226-233. DOI: 10.1264/jsme2.ME11299.

10. Fleming, S., \& Groot, W.J. (1979). Preparation of high-fructose syrup from the tubers of the Jerusalem artichoke (Helianthus tuberosus). CRC Critical Reviews in Food Science and Nutrition. 12 (1), 1-28.

11. Fraser, D., Milligan, B.N., Pajor, E.A., Philips, P.A., Taylor, A.A., \& Weary, M.A. (1998). Behavioral perspectives on weaning in domestic pigs. In M.A. Varley \& J.P. Chadwick (Eds.), Pig Science (pp. 121138). Nottingham: Nottingham University Press.

12. Govil, K., Yadav, D., Patil, A., Nayak, S., Baghel, R., Yadav, P., \& Thakur, D. (2017). Feeding management for early rumen development in calves. Journal of Entomology and Zoology Studies. 5(3), 1132-1139.

13. Greenberger, N.J., Saegh, S., \& Ruppert, R.D. (1968). Urine indican excretion in malabsorptive disorders. Gastroenterology. 55(2), 204-211.

14. Hasunuma, T., Kawashima, K., Nakayama, H., Murakami, T., Kanagawa, H., Ishii, T., ... Kushibiki, S. (2011). Effect of cellooligosaccharide or synbiotic feeding on growth performance, fecal condition and hormone concentrations in holstein calves. Animal Science Journal. 82(4), 543-548. DOI: 10.1111/j.17400929.2010.00861.x.

15. Hidaka, H., Eida, T., Takizawa, T., Tokunaga, T., \& Tashiro, Y. (1986). Effects of fructooligosaccharides on intestinal flora and human health. Bifido. Microflora. 5, 37-50. DOI:10.12938/bifidus1982.5.1 37.

16. Ilgaza, A., Arne, A., Gorodko, S., \& Ilgazs, A. (2016). Impact of inulin on calves’ growth and possible reduction of greenhouse gas emission. AGROFOR International Journal. 1(2), 88-94. DOI: 10.7251/ AGRENG1602088I.

17. Iqbal, M.F., Cheng, Y.F., Zhu, W.Y., \& Zeshan, B. (2008). Mitigation of ruminant methane production: current strategies, constraints and future options. World J. Microbiol. Biotechnol. 24, 2747-2755. DOI: 10.1007/s11274-008-9819-y.

18. Jackson, J.A., Riordan, H.D., \& Neathery, S.S. (2000). Urine Indican as an Indicator of Disease. Journal of Orthomolecular Medicine. 15 (1), 18-20. 
19. Jonova, S., Ilgaza, A., \& Grinfelde, I. (2017). Methane mitigation possibilities and weight gain in calves fed with prebiotic inulin. In Research for Rural Deveopment - International Scientific Conference, 17-19 May 2017, Vol.1. (pp. 265-270). Jelgava, Latvia: LLU. DOI: 10.22616/rrd.23.2017.039.

20. Jordaan, S.M., Romo-Rabago, E., McLeary, R., Reidy, L., Nazari, J., \& Herremans, I.M. (2017). The role of energy technology innovation in reducing greenhouse gas emissions: A case study of Canada. Renewable and Sustainable energy Reviews. 78, 1397-1409. DOI: 10.1016/j.rser.2017.05.162.

21. Kreišmane, Dz. (2011). Projekta ziņojums 'Siltumnīcas efektu radošo gāzu emisijas no lauksaimniecības Latvijā un to ierobežošanas pasākumi' (Project report 'Greenhouse gas emissions from agriculture sector in Latvia and its mitigation possibilities'. LLU. Retrieved January 16, 2018, from: http://zalabriviba.lv/ wp-content/uploads/lauksaimniecba-gala.pd. (in Latvian).

22. Kaufhold, J., Hammon, H.M., \& Blum, J.W. (2000). Fructo-oligosaccharide supplementation: effects on metabolic, endocrine and hematological traits in veal calves. Journal of Veterinary Medicine. A Physiology, Pathology, Clinical Medicine. 47(1), 17-29. DOI: 10.1046/j.1439-0442.2000.00257.x.

23. Kraska-Miller, M. (2014). Nonparametric statistics for the social and behavioral sciences. Boca Raton, FL: CRC Press.

24. Kristensen, T., Mogensen, L., Knudsen, M.T., \& Hermansen, J.E. (2011). Effect of production system and farming strategy on greenhouse gas emissions from commercial dairy farms in a life cycle approach. Livestock Science. 140, 136-148. DOI: 10.1016/j.livsci.2011.03.002.

25. Larson, L., Owen, F.G., Albright, J.L., Appleman, R.D., Lamb, R.C., \& Muller, L.D. (1977). Guidelines Toward More Uniformity in Measuring and Reporting Calf Experimental Data. Journal of Dairy Science. 60, 989-991. DOI: 10.3168/jds.S0022-0302(77)83975-1.

26. Latvijas Zemkopības ministrija. (2017). Lauksaimniecības gada ziņojums (Agricultural Anual Report). (In Latvian). Retrieved January 16, 2018, from: http://www.zm.gov.lv/lauksaimnieciba/statiskas-lapas/ lauksaimniecibas-gada-zinojumi?nid=531\#jump.

27. Lenerts, A., Popluga, D., \& Rivza, P. (2017). Selection of greenhouse gas emission-reducing measures with analytic hierarchy process approach: A case study from Latvian crop production sector. In International Conference Economic Science for Rural Development, 27-28 April 2017 (pp. 267-273). Jelgava: LLU.

28. Loh, Z., Chen, D., Bai, M., Naylor, T., Griffith, D., Hill, J., ... Edis, R. (2008). Measurement of Greenhouse Gas Emissions From Australian Feedlot Beef Production Using Open-Path Spectroscopy and Atmospheric Dispersion Modeling. Australian Journal of Experimental Agriculture. 48(2), 244-247. DOI: 10.1071/ EA07244.

29. Lord, R.S., \& Bralley, J.A. (2008). Clinical Applications of Urinary Organic Acids. Part 2. Dysbiosis Markers. Alternative Medicine Review. 13(4), 292-306.

30. Martin, C., Morgavi, D.P., \& Doreau, M. (2010). Methane mitigation in ruminants: from microbe to the farm scale. Animal. 4(3), 351-365. DOI: 10.1017/S1751731109990620.

31. McGuffey, R.K., Richardson, L.F., \& Wilkinson, J.I.D. (2001). Ionophores for Dairy Cattle: Current Status and Future Outlook. Journal of Dairy Science. 84, 194-203. DOI: 10.3168/JDS.S0022-0302(01)70218-4.

32. Mul, A.J. (1997). Application of oligofructose in animal feeds. In Proceedings of International Symposium Non-Digestible Oligosaccharides: Healthy Food for colon?, 4-5 December, 1997, (p. 106). Wageningen, The Netherlands: Wageningen Pers.

33. Mwenya, B., Santoso, B., Sar, C., Gamo, Y., Kobayashi, T., Arai, I., \& Takahashi, J. (2004). Effects of including $\beta 1-4$ galacto-oligosaccharides lactic acid bacteria or yeast culture on methanogenesis as well as energy and nitrogen metabolism in sheep. Animal Feed Science and Technology. 115(3-4), 313-326. DOI: 10.1016/j.anifeedsci.2004.03.007.

34. Nabuurs, M.J.A. (1998). Weaning piglets as a model for studying pathophysiology of diarrhea. Veterinary Quarterly. 20(3), 42-45. DOI: 10.1080/01652176.1998.9694967.

35. Öztürk, H. (2008). Effects of inulin on rumen metabolism in vitro. Ankara Üniv Vet Fak Derg. 55, 79-82.

36. Rother, M., \& Krzycki, J.A. (2010). Selenocysteine, pyrrolysine, and the unique energy metabolism of methanogenic archaea. Archaea. 2010, 1-14. DOI: 10.1155/2010/453642.

37. Samanta, A.K., Jayapal, N., Senani, S., Kolte, A.P., \& Sridhar, M. (2013). Prebiotic inulin: Useful dietary adjuncts to manipulate the livestock gut microflora. Brazilian Journal of Microbiology. 44(1), 1-14. DOI: 10.1590/S1517-83822013005000023.

38. Shibata, M., \& Terada, T. (2010). Factors Affecting Methane Production and Mitigation in Ruminants. Animal Science Journal. 81, 2-10. DOI: 10.1111/j.1740-0929.2009.00687.x.

39. Smith, E.A., \& Macfarlane, G.T. (1997). Formation of Phenolic and Indolic Compounds by Anaerobic Bacteria in the Human Large Intestine. Microbial Ecology. 33(3), 180-188. DOI: 10.1007/s002489900020. 
40. Toskes, P.P. (1999). The changing nature of small intestine bacterial overgrowth. Current Gastroenterology Reports. 1(4), 267-268. DOI: 10.1007/s11894-999-0107-2.

41. Verdonk, J.M.A.J., \& Van Leeuwen, P. (2004). The application of inulin type fructans in diets for veal calves and broilers. In 4th Orafti Research Conference - Inulin and Oligofructose Feed Good Factors for Health and Well Being, 12-13 February, 2004, (pp. 50-51). Paris, France. 